\title{
ANALIZA PRZESTRZENNA OSADNICTWA WYSPY WOLIN I PRAWEGO BRZEGU DZIWNY OD ŚRODKOWEGO OKRESU EPOKI BRĄZU DO WCZESNEJ EPOKI ŻELAZA
}

(autoreferat wygłoszony w trakcie obrony pracy doktorskiej w dniu 5 marca 2004 r.)

Opracowanie jest poświęcone analizie przestrzennej osadnictwa wyspy Wolin i prawego brzegu Dziwny w młodszej epoce brązu i wczesnej epoce żelaza oraz interpretacji jej wyników. Z powodów technicznych praca podzielona jest na dwie części: część tekstową (analityczną) oraz katalog źródeł. Na część tekstową składa się siedem rozdziałów.

Rozdział I zawiera standardowe w opracowaniu naukowym zdefiniowanie celu i zakresu pracy. Dość szczegółowo omówiony został stan badań - zwłaszcza w zakresie treści (i wartości poznawczej) przekazów archiwalnych oraz publikacji źródłowych. Ważną rolę przypisano także ocenie stopnia rozpoznania osadnictwa na poziomie badań terenowych. Omówienie stanu badań nad osadnictwem ludności kultury łużyckiej na Pomorzu pozwoliło na skrótowe przedstawienie najważniejszych opracowań dotyczących tej problematyki.

Rozdział II poświęcony jest zagadnieniom geologii i geomorfologii. W syntetyczny sposób zaprezentowana tu została geologiczna historia Morza Bałtyckiego od schyłku plejstocenu do czasów nowożytnych. Szczególną uwagę poświęcono procesom wpływającym na zmienność linii brzegowej południowego Bałtyku, w tym zachodniego odcinka wybrzeża Pomorza Zachodniego. W ten sposób możliwe było objaśnienie zjawisk odpowiedzialnych za kształtowanie się estuarium Odry, a przede wszystkim - za budowę i zarys wyspy Wolin. W konsekwencji możliwe stało się odejście od kartograficznego odwzorowania współczesnego Wolina na rzecz wyobrażenia bliższego rzeczywistości przełomu okresu subborealnego i subatlantyckiego.

Rozdział III jest najobszerniejszą częścią opracowania. Jego wewnętrzny układ odpowiada kolejnym etapom procesu badawczego. Na wstępie rozważono niektóre cechy obszaru, na którym znajduje się badany układ, i ich potencjalny wpływ na późniejsze wyniki prac. Czesść metod analizy przestrzennej, jakie planowano zastosować (tzw. metody powierzchniowe) wymaga przeprowadzenia podziału obszaru badań na kwadraty. Zanalizowano konsekwencje różnych konstrukcji siatki definiującej taki podział. Uznano, że stosowane dotąd rozwiązania nie uwzględniają w dostateczny sposób warunku porównywalności wszystkich modułów, jeśli zarys obszaru badań posiada granice naturalne (jest nieumiarowy). Zredukowano więc standardową siatkę podziału terenu do figury 
o zarysie opisanym na konturze obszaru badań. Ponadto (jako opcję dalszych analiz) zaproponowano przeliczenie zawartości kwadratów niepełnych (brzegowych).

Zestawiony katalog źródeł zawiera m.in. znaleziska i odkrycia o bliżej nieustalonej chronologii lub pozbawione bliższej lokalizacji. Uznano, że ich bezrefleksyjne pominięcie byłoby działaniem pochopnym. W efekcie wiarygodność procedur analizy i ich wyników mogłaby być znacznie obniżona. $Z$ tego powodu zdecydowano się na zastosowanie analizy rozkładów dwóch zmiennych $w$ celu określenia zbieżności rozkładów znalezisk tych kategorii źródeł z pozostałymi rozkładami.

Na podstawie oceny zgodności rozkładów dwóch zmiennych ustalone zostały cechy rozkładów zdarzeń chronologicznie niedookreślonych oraz znalezisk luźnych na obu częściach obszaru badań: na wyspie Wolin i na prawym brzegu Dziwny. Na wyspie Wolin rozkład zdarzeń chronologicznie niedookreślonych odpowiada rozkładowi zdarzeń datowanych na epokę brązu. $Z$ tego powodu zdecydowano się połączyć te zbiory; w dalszych badaniach analizom poddawano więc rozkład sumy tych zdarzeń. Natomiast na prawym brzegu Dziwny nie stwierdzono takiego podobieństwa, wobec czego zdarzenia pozbawione bliższej chronologii zostały tam pominięte $w$ dalszych pracach. W ten sposób ostatecznie zdefiniowano zespoły źródeł tworzących badane rozkłady zdarzeń.

W celu określenia cech rozkładów jednej zmiennej zastosowano dwie zasadnicze grupy metod analizy przestrzennej. Metody „powierzchniowe” odwołują się do podziału terenu badań na jednakowej wielkości obszaru; podział taki realizowany jest za pomocą siatki kwadratów. Metody „odległościowe” polegają na wyznaczeniu dystansu dzielącego każde ze zdarzeń od jego najbliższego sąsiada. W celu ułatwienia formułowania późniejszych interpretacji określono również przebiegi zmienności wybranych wskaźników dla predefiniowanych rozkładów modelowych (maksymalnie skupionego i idealnie regularnego). Szczególnie dużo miejsca poświęcono triangulacji i proponowanym modyfikacjom tej metody.

Na obu częściach obszaru badań zanalizowano rozkłady zdarzeń datowanych na epokę brązu oraz na wczesną epokę żelaza. Zdecydowano się również na zdefiniowanie serii wariantów rozkładów zdarzeń, przez co możliwe stało się wykorzystanie wniosków wynikających z wcześniejszych rozważań metodycznych i źródłoznawczych.

W przypadku zastosowania metod ,powierzchniowych" dla każdego ze zdefiniowanych wyżej czterech rozkładów wyznaczono trzy warianty. Wariant pierwszy - określany jako pods ta w o wy - obejmował rozkłady o liczebności oraz lokalizacji zdarzeń wynikających tylko i wyłącznie z katalogu źródeł. Wariant ten był więc standardowa aplikacja tych metod, znanych na przykład z opracowań geograficznych.

Wariant drugi - nazywany przeliczonym - dotyczył rozkładu, w którym liczebność zdarzeń została zmodyfikowana. Potrzeba tej modyfikacji wynikała z niezgodności zarysu siatki, jaką wykorzystano do przeprowadzenia podziału terenu, z naturalnym (a więc nieregularnym) zarysem jego granic. W rozkładzie tym podwojono zawartości tych brzegowych oczek sieci, których powierzchnia zajęta była przez rzeczywisty obszar badań nie więcej niż w połowie. 
Wariant trzeci - oznaczony jako rozkład stanowisk osadowych - jest wersją rozkładu przeliczonego, zredukowanego do stanowisk stricte osadowych. Pominięto tutaj zarówno cmentarzyska, znaleziska gromadne (skarby), jak i tzw. znaleziska luźne.

W przypadku metod „odległościowych" zdecydowano się na wykonywanie wszystkich analiz dla dwóch zasadniczych wariantów rozkładów. W przyjętym podziale chronologicznym pierwszy z wariantów obejmuje wszystkie zdarzenia, natomiast drugi wyłącznie te zdarzenia, którym w katalogu przypisano funkcję osad.

Swoistą metodą analizy przestrzennej odwołującej się do pomiarów odległości jest triangulacja. W literaturze przedmiotu wskazano na jej walory w badaniach zmiennych przestrzennie ciagłych, w których wizualizacją wyników jest izolinia lub grupa izolinii. Podejście takie jest możliwe do zastosowania wówczas, gdy zbiór danych ma postać układu punktów w przestrzeni, z których każdy posiada przypisaną sobie liczbę, wskazującą na wartość występującej tam zmiennej. Krzywa (izolinia) będąca efektem interpolacji oddawać będzie nie tylko wielkość zmiennej w każdym z punktów układu, ale pozwoli także na określenie wartości analizowanej zmiennej w dowolnym miejscu przestrzeni objętej interpolacją.

Jak wskazują przykłady aplikacji triangulacji prezentowane w opracowaniach archeologicznych, możliwe jest zastosowanie tej metody także w analizach rozkładów punktowych (zmiennych przestrzennie nieciaglych). Ich celem nie jest wówczas interpolacja i wykreślenie izolinii, ale zbadanie cech rozkładu punktów. Metoda triangulacji nie odwołuje się przy tym do obliczania wskaźników czy statystycznego testowania istotności otrzymanych wyników, a jedynie do wizualizacji pewnych danych i ich interpretacji.

Pierwszym etapem analizy rozkładu punktowego (zdarzeń) metodą triangulacji jest zbudowanie tzw. grafu rozpiętego na punktach rozkładu. Polega to na zastosowaniu zasad wykorzystywanych na przykład w geodezji czy kartografii na wstępnym etapie prac związanych z kreśleniem planów warstwicowych. Pomiarowi podlega tutaj dystans z danego punktu do punk tów jemu najbliższych w taki sposób, aby odcinki wyznaczające pomiar nie przecinały się wzajemnie i stworzyły układ trójkątów. Prowadzi to do skonstruowania grafu rozpiętego na punktach rozkładu. Jeżeli krawędzie grafu wyznaczają odległości mierzone między punktami rozkładu, to sam graf jest niczym innym jak graficznym obrazem zbioru danych, który następnie zostanie poddany analizie i interpretacji. Zbiór odległości wyznaczonych przez krawędzie grafu podlega następnie wizualizacji w formie wykresu skumulowanego. Zauważalne na wykresie przedziały nadreprezentacji stanowią podstawę do skonstruowania siatki sześciokątów (tzw. siatki Christallera). Ostateczna interpretacja rozkładu zależna jest od tego, czy zdarzenia lokują się w węzłach siatki (co ma wskazywać na hierarchiczność rozkładu), czy też wewnątrz oczek (co ma dowodzić jego regularności).

Powyższa procedura poddana została analizie z punktu widzenia metodyki, a następnie pewnej modyfikacji. Modyfikacja ta polegała na eliminacji tych krawędzi grafu, które naruszały granice obszaru badań, usunięto również krawędzie o długości przekraczającej $10 \mathrm{~km}$. Opracowany w ten sposób graf stał się podstawą sporządzenia standardowego 
wykresu skumulowanego. Kolejne zmiany wprowadzono na etapie interpretacji przebiegu krzywej. Zrezygnowano $z$ budowy jednolitej siatki sześciokątów na rzecz wyznaczania indywidualnych poligonów dla wybranych punktów rozkładu. Cała analiza sprowadzona została w ten sposób na niższy, bardziej indywidualny - bo odwołujący się do konkretnych, pojedynczych zdarzeń - poziom. Pozwala to zarówno na wskazanie zdarzeń tworzących „,szkielet” czy „osnowę” struktury, jak i na scharakteryzowanie ich relacji z pozostałymi zdarzeniami. Szczególne interesujące wydają się kwestie powtarzalności zjawisk (np. w aspekcie funkcji zdarzeń kreujących poszczególne poligony czy kontekstów im towarzyszących), a także relacji poligonów do ogółu zdarzeń tworzących rozkład oraz relacji serii poligonów dowodzących istnienia układu hierarchicznego. Celem analizy krzywej jest więc wykrycie cech wskazujących na nielosowy charakter badanego rozkładu rzeczywistego.

Znaczenie podstawowe dla formułowania tego rodzaju wniosków ma analiza przebiegu wykresu skumulowanych odległości. Odcinki krzywej świadczące o niedoreprezentacji jakiegoś przedziału odległości mogą świadczyć o obecności układów skupionych (wartości poniżej tego przedziału dotyczą raczej relacji między zdarzeniami wewnątrz skupienia, natomiast wartości powyżej tego przedziału - relacji między zdarzeniami należącymi do różnych skupień). W przypadku odcinków krzywej wskazujących na nadreprezentację pewnego przedziału odległości można oczekiwać wykazania pewnych cech regularności rozkładu.

Interpretacje powyższe zostały sformulowane na podstawie efektów triangulacji wykonanych dla serii rozkładów o znanych cechach. Stwierdzenia z nich wynikające posiadają znaczenie fundamentalne dla identyfikacji cech rozkładów rzeczywistych. $Z$ tego też powodu postanowiono sprawdzić ich zasadność poprzez sporządzenie triangulacji i wykresów skumulowanych dla wygenerowanych rozkładów punktów losowych. Zabieg ten pozwala na uzyskanie materiału porównawczego, a w efekcie - na zwiększenie wiarygodności wnioskowania odnoszącego się do badanych rozkładów rzeczywistych.

Dążąc do zapewnienia możliwie dużej porównywalności rozkłady losowe umieszczono w kontekstach rzeczywistej przestrzeni obu części obszaru badań, tj. wyspy Wolin i prawego brzegu Dziwny. W obu przypadkach rozkłady losowe poddano procedurom analogicznym do zastosowanych w przypadku analizowanych rozkładów EB i WEŻ. Zgodnie z przyjętymi założeniami usunięto więc te krawędzie grafu, które były siecznymi granic obszaru badań. W konstrukcji wykresów pominięto także krawędzie o długościach przekraczających $10 \mathrm{~km}$. Na podstawie sporządzonych wykresów skumulowanych stwierdzono, że przebieg krzywych dla rozkładów losowych jest regularny i nie występują tam żadne istotne zakłócenia (przedziały nad- lub niedoreprezentowane).

Analiza wykresów sporządzonych dla rozkładów rzeczywistych polegała na badaniu ich przebiegu, a także na odnoszeniu ich do „wzorcowego” dla danej części obszaru badań wykresu rozkładu losowego. Porównywano również wzajemnie wykresy wykonane dla obu wariantów danego rozkładu, próbując dociec w ten sposób ewentualnych różnic i wpływu stanowisk nieosadowych na cechy rozkładu. Natomiast zestawienie par 
rozkładów w układzie diachronicznym umożliwiło wnioskowanie o zmienności struktur, a więc o procesach osadniczych.

Zastosowane metody analizy przestrzennej pozwolily na uchwycenie pewnych cech szczególnych badanych rozkładów. W większości metody te poparte są bogatą literaturą omawiającą wyniki ich aplikacji - także w odniesieniu do źródeł archeologicznych. Z tego powodu prezentowane niżej syntetyczne zestawienie wniosków wynikających $\mathrm{z}$ ich zastosowania pozwala na bezpośrednie porównanie. Zachowano jedynie podział wynikający z charakteru obu głównych grup metod analizy przestrzennej.

Metody ,powierzchniowe” analizy przestrzennej niekiedy ocenianie są jako „słabsze" niż metody odległościowe. Jednak możliwość uwzględnienia w ich zastosowaniu wszystkich zdarzeń - także tych o niepewnej lokalizacji - ma kapitalne znaczenie. Z tego też powodu wyniki analiz ,powierzchniowych” mają dużą wartość poznawczą. W procesie interpretacji rozkładów badanych w niniejszej pracy rezultaty obu tych grup metod traktowano w sposób podobny.

\section{WYNIKI BADAŃ}

Podsumowując wyniki przeprowadzonych badań, można stwierdzić, że dla rozkładu zdarzeń EB na wyspie Wolin wyniki większości testów wskazują na nielosowy charakter rozkładu, przy czym hipotezy alternatywne - jeśli dany test pozwala na ich zdefiniowanie - wskazują na tendencje do skupiania się zdarzeń. Natomiast w przypadku rozkładu zdarzeń WEŻ tamże wyniki znacznej części testów (dla wariantu podstawowego) lub ich znakomitej większości (dla wariantu osadowego) prowadzą do odrzucenia hipotezy zerowej. Hipotezą alternatywną (jeżeli dany test pozwala na jej sprecyzowanie) jest regularność rozkładu.

Dla rozkladu EB na prawym brzegu Dziwny większość testów wskazuje na jego losowy charakter, jedynie wskaźnik Steinhausa i test Hopkinsa sugerują pewną regularność w rozkładzie zdarzeń wariantu osadowego. Wyniki triangulacji wskazują na obecność pewnych skupień zdarzeń. W przypadku rozkładu zdarzeń WEŻ na prawym brzegu Dziwny wyniki większości testów dowodząjego nielosowego charakteru. Testy umożliwiające sformułowanie hipotezy alternatywnej wskazują na pewne tendencje do skupiania się. Wyniki triangulacji dla rozkładu ogółu zdarzeń (wariant podstawowy) dowodzą jego skupionego charakteru. Natomiast w przypadku wariantu osadowego rozkładu WEŻ wykres skumulowany nie pozwala na sformułowanie jakichkolwiek wniosków.

\section{CHARAKTERYSTYKA STRUKTUR OSADNICZYCH WYSPY WOLIN}

Wnioski dotyczące osadnictwa epoki brązu na terenie wyspy Wolin są stosunkowo skromne. Wyniki większości testów sugerują pewną tendencję do skupiania się zdarzeń tworzących ten rozkład. Analiza ich rozmieszczenia na mapie wskazuje, że jest to efekt 
obecności serii zdarzeń rozlokowanych w centralnej części wyspy. Powstała w ten sposób strefa koncentracji nie wykazuje jednak oznak wewnętrznego uporządkowania, które mogłoby dawać asumpt do formułowania dalszych wniosków. Także rozkłady innych kategorii zdarzeń na wyspie (np. cmentarzysk) same nie stanowią takich podstaw.

Znacznie lepsze efekty przyniosło badanie rozkładu zdarzeń datowanych na WEŻ na Wolinie. Porównano przy tym pewne cechy rozkładu zdarzeń WEŻ z rozkładem zdarzeń EB. Przy okazji aplikacji metod „powierzchniowych” stwierdzono, że zasięg ekumeny zajętej przez osadnictwo WEŻ w stosunku do EB istotnie się zmniejszył. W tym kontekście ciekawe jest porównanie wartości średnich arytmetycznych odległości do najbliższego sąsiada. W przypadku wyspy Wolin średnie te dla obu wariantów rozkładu WEŻ są w przybliżeniu dwukrotnie większe, niż dla odpowiadających im wariantów rozkładu EB ( $1,58 \mathrm{~km}$ dla wariantu podstawowego WEŻ i $1,95 \mathrm{~km}$ dla jego wariantu osadowego wobec $0,88 \mathrm{~km}$ dla EB podstawowego i $0,93 \mathrm{~km}$ dla EB osadowego).

Wyniki analiz stały się punktem wyjścia budowy modelu struktury osadnictwa WEŻ na wyspie Wolin, przy czym znaczenie zasadnicze miała analiza krzywej skumulowanej odległości wyznaczonych dla tego rozkładu metodą triangulacji. Na wykresie wyznaczono dwa nadreprezentowane przedziały odległości - pierwszy o średniej wartości ok. $3,7 \mathrm{~km}$ i drugi o średniej wartości ok. 6,5 km. Następnie wyszukano krawędzie grafu o zbliżonych do nich długościach. W ten sposób możliwe było wskazanie punktów rozkładu, wokół których następnie zbudowano okręgi o promieniu równym połowie powyższych średnich. Okręgi te zostały zastąpione wpisanymi w nie sześciokątami.

W efekcie powyższych działań wyznaczono dwie serie poligonów, określane dalej jako wyznaczniki podziałów I i II rzędu. Należy zauważyć, że właściwe im wielkości nie są swoimi calkowitymi wielokrotnościami. Pomimo to granice poszczególnych poligonów należących do podziału I rzędu ( $\mathrm{dla} r=1,85 \mathrm{~km}$ ) nigdy nie naruszają w istotniejszy sposób granic wyznaczanych przez poligony podziału II rzędu (dla $r=3,25 \mathrm{~km}$ ).

Jak się wydaje, podziałom I rzędu można przypisać pewne znaczenie ekonomiczne. Podziały te mogły być związane z kolektywną kontrolą terenów rolniczych (rzeczywiście wykorzystywanych i potencjalnych). Stąd jeśli jego wyznacznikami są - obok osad otwartych - także grodziska, to może to oznaczać, że zamieszkująca je ludność prowadziła uprawę roli na poziomie i w skali odpowiadającej społecznościom zamieszkującym osady otwarte. Trzeba jednak podkreślić, że sprowadzenie całego zjawiska do poziomu czysto materialnego (gospodarczego) byłoby nadmiernym uproszczeniem.

Poligony wyznaczone dla niektórych zdarzeń w istocie mają mniejszą powierzchnię, gdyż zdarzenia te zlokalizowane są w sąsiedztwie granic obszaru badań. Duże znaczenie w wyjaśnianiu tego rodzaju sytuacji może mieć określenie funkcji stanowisk, które mają takie właśnie niepełne poligony. Wszystkie te stanowiska dysponują specjalnymi funkcjami: są to 3 grodziska (katalog stanowisk z wyspy Wolin, poz. 6, 24 i 42) oraz osada w Wolinie (katalog, poz. 90). Rozważania na temat rzeczywistej roli grodów rozwinięte zostaną niżej; w tym miejscu wystarczy zaznaczyć, że czynniki decydujące o wzniesieniu grodu wpływały zapewne również na decyzję o jego lokalizacji. $Z$ tego powodu zbyt dużym uproszczeniem jest mechaniczne stosowanie $w$ odniesieniu do nich ogólnych 
reguł mających konotacje czysto gospodarcze. Wyjątkową pozycją odznacza się również osada w Wolinie, dla której istotnym czynnikiem - także o znaczeniu ekonomicznym - były kontakty ze społecznościami zamieszkującymi przeciwległy brzeg Dziwny. Ponadto - $\mathrm{z}$ gospodarczego punktu widzenia - społeczności zajmujące wszystkie cztery stanowiska mogły korzystać $\mathrm{z}$ bezpośredniego położenia nad wodą i uprawiać rybołówstwo (które jest dobrze poświadczone dla osady w Wolinie).

Być może więc zasadne byłoby przeformułowanie stwierdzenia przedstawionego wyżej w sposób następujący: w aspekcie całości reguł (jakiekolwiek by one były), które stanowiły o powszechnie uznawanym sposobie podziału przestrzeni, ludność zamieszkująca grody nie była w żaden widoczny sposób uprzywilejowana w stosunku do mieszkańców osad otwartych.

W proponowanym modelu wyznacznikami podziałów II rzędu są wyłącznie osady otwarte, przy czym znaczna część z nich ma „długą" chronologię, obejmującą EB-WEŻ (katalog stanowisk z wyspy Wolin, poz. 16, 39, 41, 59, 81 i 90). Świadczyć to musi o ewolucyjnym, rozciagniętym $w$ czasie procesie wykształcania się struktur opisywanych tutaj w formie statycznej, skończonej i w istocie - sztucznie odrębnej od obrazu osadnictwa w EB.

Wydzielone w strukturze osadnictwa podziały II rzędu - jeśli mają wymiar „ekonomiczny” czy „gospodarczy” - mogą być związane na przykład z innymi aspektami eksploatacji środowiska (zbieractwo/łowiectwo, ale i na przykład kontrola zasobów paszy dla hodowanych zwierząt, budulca czy opału). Nie jest to niewątpliwie jedyny kontekst, jaki można w tym przypadku wskazać.

Proponowany model obejmuje wszystkie kategorie stanowisk, jakie zarejestrowano na terenie wyspy Wolin. Model ten jako struktura stanowi inną jakość niż prosta suma jego składników, wobec czego możliwe jest sformułowanie pewnych spostrzeżeń dotyczących miejsca i znaczenia niektórych jego elementów, tj. grodów, cmentarzy i skarbów.

Zgodnie z katalogiem źródeł wśród stanowisk archeologicznych znanych z wyspy Wolin występują 3 grodziska (katalog stanowisk z wyspy Wolin, poz. 6, 24 i 42). W interpretacji rozkładu zdarzeń WEŻ wszystkie 3 stanowiska są elementami I rzędu podziału terenu (poligony dla $r=1,85 \mathrm{~km}$ ). Jak już zauważono, na tym poziomie organizacji przestrzeni społeczności zamieszkujące grody nie wyróżniały się na tle ogółu zajmującego osady otwarte. Co ciekawe, żadne z grodzisk nie stanowi centrum dla drugiego poziomu podziału terenu (poligony dla $r=3,25 \mathrm{~km}$ ). Jeśli więc grody pełniły jakąś rolę szczególną w systemie osadniczym, to nie była ona podkreślana przez „przypisanie im” terenu większego niż każdej stałej osadzie otwartej stanowiącej element podziału I rzędu.

Interpretując zmiany charakteru rozkładów zdarzeń na wyspie Wolin, warto również sięgnąć do wyników uzyskanych w toku badania zgodności rozkładów dwóch zmiennych. Dokonane wówczas zliczenia dowodza, że zasięg ekumeny we WEŻ uległ silnej redukcji w stosunku do EB. Jednocześnie osadnictwo praktycznie nie objęło wówczas nowych terenów. W tym kontekście znaczenia nabierają inne ustalenia, dotyczące rozmieszczenia cmentarzysk. Badając rozkłady dwóch zmiennych wyznaczono m.in. tzw. 
wskaźnik asocjacji A dla cmentarzysk na Wolinie. Obliczono przy tym, że pomimo zmniejszenia się obszaru zajętego przez osadnictwo WEŻ, średnia odległość pomiędzy cmentarzyskami jest dla tego okresu większa niż w przypadku rozkładu zdarzeń EB $(6,69 \mathrm{~km}$ wobec $5,14 \mathrm{~km})$.

Należy podkreślić, że wartość średniej dla cmentarzysk WEŻ jest bardzo bliska drugiej wartości nadreprezentowanej na wykresie skumulowanym triangulacji (ok. $6,5 \mathrm{~km}$ ) dla rozkładu WEŻ w jego wariancie osadowym (a więc tym, z konstrukcji którego cmentarzyska zostały wyłączone). Zbieżność ta (przy pełnej rozłączności zbiorów będących podstawą przytoczonych wyliczeń) wydaje się nieprzypadkowa. Jednocześnie analizując lokalizację cmentarzysk wobec wyznaczonych na tym poziomie poligonów można zauważyć, że znakomita większość z nich znajduje się w strefie ich krawędzi. Prawdopodobnie $w$ strukturze zasiedlenia i systemie kontroli terenu cmentarze pełniły funkcję markerów podziału czy swoistych „kamieni granicznych”. Sugestię taką może potwierdzać obecność par ,punktów sklejonych” - blisko obok siebie zlokalizowanych cmentarzy o tej samej chronologii. Przyjmując zasadność powyższej hipotezy, cmentarze te, użytkowane równocześnie przez sąsiadujące społeczności, byłyby jednocześnie wyznacznikiem granic należącego do każdego z nich terytorium. Akt lokacji takiego ,świadectwa własności" byłby więc efektem autonomicznej decyzji danej społeczności (choć w części przypadków, zapewne sprowokowanej przez podobne działanie sąsiadów). W ten sposób poprzez złożenie prochów przodków legitymizowało prawo do ziemi; kolejne pochówki prawo to stale odnawiały i potwierdzały.

Ostatnią kategorią zdarzeń, jaką uwzględniono w proponowanym obrazie struktur osadnictwa WEŻ na wyspie Wolin, są skarby. Pewną niedogodnością jest tutaj brak precyzyjnej lokalizacji większości tego typu znalezisk. Okoliczność ta nie uniemoźliwia jednak podjęcia próby określenia ich relacji do pozostałych elementów tworzących omawianą strukturę.

Przed przystąpieniem do formułowania spostrzeżeń na ten temat należy podkreślić zróżnicowany charakter skarbów znanych z wyspy Wolin. I tak skarb z Wolina (katalog stanowisk z wyspy Wolin, poz. 89) zdeponowany został w ziemi, w kłodzie drewnianej, na terenie osady lub w jej bezpośrednim sąsiedztwie. Okoliczności te moga wskazywać na niezrealizowany zamiar jego późniejszego podjęcia. $Z$ tego powodu lokalizacja tego znaleziska nie wydaje się bezpośrednio istotna dla rozważań na temat struktury osadnictwa, choć niewątpliwie wskazuje na znaczenie osady, w której musiał mieszkać indywidualny bądź kolektywny dysponent złożonego w ziemi zespołu brązów.

Skarb z Warnowa (katalog stanowisk z wyspy Wolin, poz. 79), z uwagi na swój kontekst (depozyt w naczyniu glinianym, na wzniesieniu), także wydaje się mieć charakter tezauryzacyjny. Znalezisko z Warszowa (katalog, poz. 80) nie było w ogóle uwzględniane w toku prowadzonych analiz ze względu na datowanie nieco wcześniejsze niż ramy chronologiczne opracowania.

W przypadku skarbu z Międzyzdrojów (katalog, poz. 53), wątpliwego chronologicznie, nie mamy żadnych informacji na temat okoliczności odkrycia. Wnosząc jednak ze składu tworzących go przedmiotów, należy uznać, że był to „skarb odlewnika”, wobec 
czego jego lokalizacja zapewne nie ma bezpośredniego związku z cechami struktury osadnictwa wyspy.

Wyjątkowy charakter ma natomiast seria znalezisk z Kodrąbia (katalog, poz. 28-33). Wszystkie tamtejsze odkrycia (zespoły oraz pojedyncze przedmioty) były ewidentnymi depozytami bagiennymi. Fakt ich odkrywania podczas ekploatacji torfu, w odstępach kilku-czy kilkunastoletnich, wskazuje zaś, że akt ich depozycji miał charakter cykliczny, a nie jednorazowy. Topienie w wodzie czy w bagnie przedmiotów wykonanych z brązu w wyniku powtarzalnych działań uznawane jest za przejaw zabiegów magicznych, zaś miejsce dokonywania takich czynności - za sakralne.

Niestety, nie jest znana dokładna lokalizacja znalezisk kodrąbskich. Warto jednak zanalizować przebieg granic Kodrąbia jako miejscowości oraz lokalne ukształtowanie terenu (zasięg tamtejszych bagien i torfowisk). Można w ten sposób wskazać wszystkie bagna i torfowiska znajdujące się na terenie Kodrąbia. Odnosząc ich rozmieszczenie do wyznaczonych poligonów, należy zauważyć, że związane z nimi odkrycia lokują się w strefie znajdującej się u zbiegu trzech poligonów II rzędu. Okoliczność taka wskazywałaby bezpośrednio na ponadlokalne znaczenie tego miejsca. Wydaje się, że możliwe byłoby nawet przypisanie mu funkcji szczególnej w skali calej wyspy, na co może wskazywać „eksterytorialna” - w stosunku do stref kontrolowanych przez mniejsze społeczności - lokalizacja. W ten sposób zapewniony tam byłby wolny i równy dostęp dla wszystkich. Takie wyłączenie z domeny partykularnych wpływów czy uniemożliwienie zawlaszczenia tego miejsca, musi podkreślać jego duże znaczenie dla kultury duchowej, dowodzi też poczucia wspólnoty całej populacji zamieszkującej wówczas wyspę Wolin.

\section{CHARAKTERYSTYKA STRUKTUR OSADNICZYCH PRAWEGO BRZEGU DZIWNY}

W przypadku rozkładów obserwowanych na obszarze prawego brzegu Dziwny nie uchwycono podobnych zmian jakościowych. Dla osadnictwa epoki brązu ustalono istnienie wewnętrznie uporządkowanych stref koncentracji, jednak nie udało się zbudować dla nich modelu struktury uwzględniającej inne niż osady kategorie odkryć. W przypadku osadnictwa wczesnej epoki żelaza w ogóle nie było możliwe zdefiniowanie jakichkolwiek struktur. Okoliczność ta wynika częściowo ze stanu rozpoznania źródeł, nie wydaje się jednak, aby błędy w interpretacji funkcji niektórych stanowisk mogły tak radykalnie zniekształcić obraz osadnictwa. Najważniejszym wnioskiem, jaki wynika z porównania osadnictwa wczesnej epoki żelaza i epoki brązu na prawym brzegu Dziwny, jest istotne przesunięcie punktu ciężkości osadnictwa w obrębie południowej części obszaru. Zjawisko to jest widoczne w aplikacjach metod ,powierzchniowych”, „odległościowych" (triangulacja), a także przy wyznaczeniu średniej arytmetycznej współrzędnych zdarzeń.

Rozdział $\mathrm{V}$ poświęcono interpretacji archeologicznej zdefiniowanych wcześniej konstrukcji. W tym celu odwołano się m.in. do studiów nad osadnictwem ludności kultury łużyckiej na Pomorzu i w Wielkopolsce. Rozpoznanie struktur osadniczych i interpretacja relacji przestrzennych łączących ich elementy jest bowiem dla interpretacji 
archeologicznej warunkiem koniecznym, ale niewystarczającym. Zarejestrowane prawidłowości opisują struktury, te zaś należy odnieść do całości procesów kulturowych, zmian środowiska przyrodniczego itd.

Ustalenia dotyczące rozkładów zdarzeń w proponowanym podziale chronologicznym można potraktować jako swoiste ,fotografie”, obrazujące dwa stany (czy dwie fazy) jednego, ciągłego procesu osadniczego. Zasadna więc wydaje się próba określenia cech tego procesu.

W przypadku wyspy Wolin można stwierdzić, że osadnictwo w epoce brązu miało układ dowolny, choć z pewnością nieprzypadkowy, czego dowodzi zauważalna asymetria w rozkładzie stanowisk na obszarze wyspy. Rozkład taki wskazuje na istnienie dość jednoznacznych preferencji w doborze siedliska. Osadnictwo we wczesnej epoce żelaza nabiera cech regularności, pojawiają się nowe formy osadnicze (grody) i nowe osady, choć nadal funkcjonuje część starych osad.

W przypadku rozkładów obserwowanych na obszarze prawego brzegu Dziwny nie uchwycono podobnych zmian jakościowych. Dla osadnictwa epoki brązu ustalono istnienie wewnętrznie uporządkowanych stref koncentracji, jednak nie udało się zbudować dla nich modelu struktury uwzględniającej inne niż osady kategorie odkryć. W przypadku osadnictwa wczesnej epoki żelaza w ogóle nie było możliwe zdefiniowanie jakichkolwiek struktur.

Porównanie zarysowanych wyżej zmian w strukturach osadniczych pozwala stwierdzić, że procesy osadnicze na wyspie Wolin przebiegały w sposób zbliżony do obserwowanego w innych mikro- czy mezoregionach osadniczych. W sytuacji, w której zazwyczaj przypisuje się duże znaczenie grodom jako szczególnym formom osadniczym, skrótowo przeanalizowano niektóre możliwości interpretacji ich funkcji i miejsca w strukturze osadnictwa. Zauważono także, że w przypadku prawego brzegu Dziwny zmiany w obrazie osadnictwa posiadały odrębny charakter i nie powielały zjawisk obserwowanych na wyspie Wolin. Ostateczne wyjaśnienie tej sytuacji na obecnym etapie badań jest trudne; możliwe, że jednym z czynników mogły być różnice w lokalnej tradycji kulturowej.

Podsumowując powyższą prezentację treści opracowania, należy podkreślić wagę przykładaną do wszelkich kwestii metodycznych. Refleksje poświęcone cechom przedmiotu badań i jego kontekstu mają zasadnicze znaczenie dla przyjętych rozwiązań metodycznych, a nawet implikują podjęcie dodatkowych analiz, takich jak analiza rozkładów dwóch zmiennych. Wprowadzenie wariantów badanych rozkładów pozwoliło z jednej strony zachować odniesienia do literatury przedmiotu, z drugiej zaś umożliwiło respektowanie założeń wprowadzonych na wstępie procedury badawczej. W niektórych przypadkach interpretacje otrzymanych wartości wskaźników poprzedzono badaniem przebiegu ich zmienności, co przyniosło dość zaskakujące rezultaty (por. wskaźnik koncentracji C) . Szczególnie dużo miejsca poświęcono triangulacji, jako że metoda ta nie była dotąd szerzej stosowana. W stosunku do jedynej znanej aplikacji triangulacji w badaniu rozkładu znalezisk archeologicznych zaproponowano istotne modyfikacje tej metody. Otrzymywane $w$ ten sposób rezultaty weryfikowane były zarówno przez wyniki 
pozostałych testów, jak i przez kontrolne badanie rozkładów punktów losowych czy częściowych rozkładów zdarzeń.

Rozbudowana kontrola rozwiązań metodycznych, jakie zastosowano na każdym etapie analizy, przydaje wiarygodności wynikom końcowym. Znaczenie tej kontroli oraz towarzyszących jej spostrzeżeń może jednak wykraczać poza potwierdzenie dbałości o rzetelność tej właśnie, jednostkowej analizy. Dzięki temu dość dobrze scharakteryzowano wykorzystany aparat badawczy. Jego efektywność wydaje się stosunkowo wysoka, na co wskazują uzyskane wyniki - zwłaszcza dla wyspy Wolin. Kolejnym krokiem mogłyby być analogiczne analizy przestrzenne dla większej liczby mikro- czy mezoregionów, przeprowadzone z zastosowaniem podobnych procedur badawczych. Pozwoliłoby to na sprawdzenie skuteczności wybranych rozwiązań metodycznych, a przede wszystkim - zmniejszyłoby dotkliwą lukę w studiach nad osadnictwem tego okresu, operujących zazwyczaj na poziomie monografii stanowiska z jednej strony lub monografii osadnictwa całych krain geograficznych z drugiej. 